\title{
Marja Härkönen 60 years
}

\author{
TARJA UKKOLA
}

\begin{abstract}
UKKOLA, T. 2000: Marja Härkönen 60 years. - Karstenia 40: 3-5. Helsinki. ISSN 0435-3402.

Tarja Ukkola, Department of Ecology and Systematics. P.O. Box 47, FIN-00014 University of Helsinki.
\end{abstract}

\begin{abstract}
Marja Elina Härkönen (neé Kotiaho) was born in Tampere in south-central Finland on 17 October 1939. She matriculated from the women's lyceum of Tampere (Tampereen tyttölyseo) in 1959 and entered the University of Turku to study biology. She became Bachelor of Science (B.Sc.) in 1962, Master of Science (M.Sc.) in 1968, and Licentiate in Philosophy in 1972 in Turku. In 1979 Marja defended her Ph.D. Thesis "Ecological, taxonomical and chorological studies on Finnish Myxomycetes" at the University of Helsinki.
\end{abstract}

Marja was still a biology student when she started her working career. In 1962-1972 she was biology and geography teacher in the secondary and high schools in Tampere, Kellokoski and Espoo. The secondary school of Tapiola where she taught in Espoo was in the forefront of educational philosophy in the 1960's and 1970's and the experimental teaching in biology and geography practised in the school well suited Marja. For instance she planned microbiological laboratory exercises and found them very popular among the pupils. Based on these experiments she compiled a work book in microbiology, and this became a success among biology teachers. Since 1971 Marja has written many articles on biology and geography teaching in Finland.

Marja Härkönen's career in the University of Helsinki began in 1974. In 1974-1983 Marja was an assistant in the Department of Botany, in 1980-1982 senior assistant. In 1981 she was appointed Lecturer (Docent) of Botany. In 19831986 Marja was a Chief Inspector of Multiple Use of Forests in the National Board of Vocational Education, in 1986-1987 an Associate Professor of Botany in the Department of Plant Biology,
Faculty of Agriculture and Forestry, University of Helsinki. In 1987 Marja returned to the Department of Botany, and was appointed her present office as senior assistant. In 1993-1998 she served as the Chairman of the Department, which, after a reorganization in 1995, was renamed as Department of Ecology and Systematics. In 1995-1996 Marja was an acting Professor of Botany, and in 1998-2000 an acting Professor of Mycology.

Marja has held many positions of trust, as well as honorary and secondary responsibilities. She was an editor of "Natura" (journal of the biology and geography teachers) in 1971-1974, an assistant member of the National Matriculation Board in 1977-1981, and a treasurer of the Finnish Biologic Society Vanamo in 1992-1998. She has been a member of several committees appointed by the National Board of Education. For instance in 1992-1995 she functioned as a professional advisor in a planning group preparing the examination of "Specialist Qualification in Utilization of Berries, Herbs and Mushrooms". Marja served as a member of the Departmental Board in the Department of Botany (1992-1995), and after establishment of the Department of Ecology and Systematics she continued on its board (1995-1997). Marja is the Chairman of Board of Directors of the Finnish Museum of Natural History since 1997.

Marja has been an active member of the Finnish Mycological Society. During 1971-1990 she served in many positions: a member of the Board of Directors, as Chairman, Vice-Chairman, a member of the Finnish Fungus Nomenclature Committee, and an editor of "Sienilehti" (popular journal of the Finnish Mycological Society), and of 
"Karstenia" (scientific journal of the Finnish Mycological Society).

Marja Härkönen is a well known myxomycologist throughout the world. When she begun her studies on myxomycetes in 1965, there was no person to teach and help her in Finland. In the late 1970's, before her dissertation, Marja visited the myxomycete systematist N. E. NannengaBremekamp in the Netherlands to obtain more guidance for her myxomycete studies. The trip was a memorable one, and Marja has told me many stories about this world-famous European, now late, myxomycologist.

Marja's first slime mould article was published in 1974. The article "Über die finnishen Schleimpilzen" compiled the knowledge of Finnish myxomycetes up to that time. Her Ph.D. thesis (1979) contained a much supplemented and improved version of the first synopsis. In addition, the ecological studies introduced in the thesis dealt with corticolous myxomycetes in Finland and Norway, and with myxomycetes growing on grain. In these extensive studies she used the moist chamber culture technique. The taxonomic part included three species new to science. She compiled the check-list of Finnish myxomyctes, which has been supplemented with thirty-eight species subsequent articles in 1981, 1988, and 1999. Marja has published over thirty scientific or popular papers dealing with myxomycetes.

In 1969, the Forest and Park Service attempted to improve the commercial use of mushrooms, and began educating commercial mushroom advisers and commercial mushroom pickers. Marja has taken part in that education, and planning of the education organized by the National Board of Vocational Education. Since 1975 she has been a Mushroom Inspector (at present, Gathered Products Inspector). Marja was one of the editors of "Guide of commercial mushrooms", published in 1983 by the National Board of Vocational Education. The revised edition, "Commercial Mushrooms" (which combined the former "Guide of commercial mushrooms", "Guide of poisonous mushrooms", and "Guide for mushroom advisers") was published in 1995. In addition to the books mentioned above, Marja has authored two other mushroom guide books, and has been one of the authors in two additional Finnish mushroom books.

In addition to Finland, Marja has studied slime molds and fungi in Gambia, Turkey, many parts of Tanzania, Russia, and China. She is almost the only ethnomycologist in Finland. For about thirty years Marja has been a specialist in public mushroom education, and, as a teacher of numerous courses of mycology, Marja is inspiring. Her own interest on fungi is noticeably, and easily transferred to the students. She has published over seventy scientific and popular papers dealing with public mushroom education, and edible and poisonous mushrooms in Finland and abroad since 1971 .

In May 1988, Marja made her first excursion to Tanzania. The field conditions in the remote villages in different parts of Tanzania, or the bureaucracy, did not frighten her and she returned to Tanzania for a total of nine field trips. The last one, made in 1995, also included dramatics: she, and some colleagues and students of her were robbed with knives on Kunduchi beach on their second day in Africa. With a knife at her throat Marja lost nearly everything: money, passport, flight-tickets, even her eye-glasses.

Her project on Tanzanian mushrooms and their uses officially began in 1990. The original plan was to mainly concentrate on ethnomycology, but it was soon realized that the most critical point was the identification of the mushrooms. The work in Tanzania, with the assistance of Tiina Saarimäki and Leonard Mwazumbi, produced the first mycological guide book of the country: "Edible mushrooms of Tanzania". It includes many new species to science, including ones with old vernacular names and a long tradition of use for food in Tanzania. In addition to the guide book, the project produced over thirty scientific and popular publications.

Marja is an energetic person, who is full of new plans. Sometimes she proceeds so rapidly that other people have difficulty in following. One example of her energy and efficiency is her functioning as the Chairman of the Department for six years while caring for duties as Senior Assistant or Associate Professor. During this same period, she continued as leader of the project on Tanzanian mushrooms and their uses, and published prolifically. Marja's first term as Chairman of the Department of Botany began in 1993. Her responsibilities included administrative tasks and bureaucracy with time for research very restricted. Despite these problems she continued that position until 1998. During her term an extensive reorganization project took place, when the biological 
departments of the university were transformed into two new, major departments: Department of Biosciences and Department of Ecology and Systematics. Decisive was Marja's role during that period in the reorganization of the biological departments of the university.

Marja has been interested in photography of plants and fungi for many years. When highquality photos are needed in publications and mycology courses, Marja's working room is the right place to find them. Another hobby is swimming, and she always has a swimming suit with her during study and congress trips. One very dear "hobby" to Marja is to take care of her five grandchildren.

The present volume is a well-deserved tribute to Marja Härkönen from her numerous colleagues and pupils in mycology and botany.

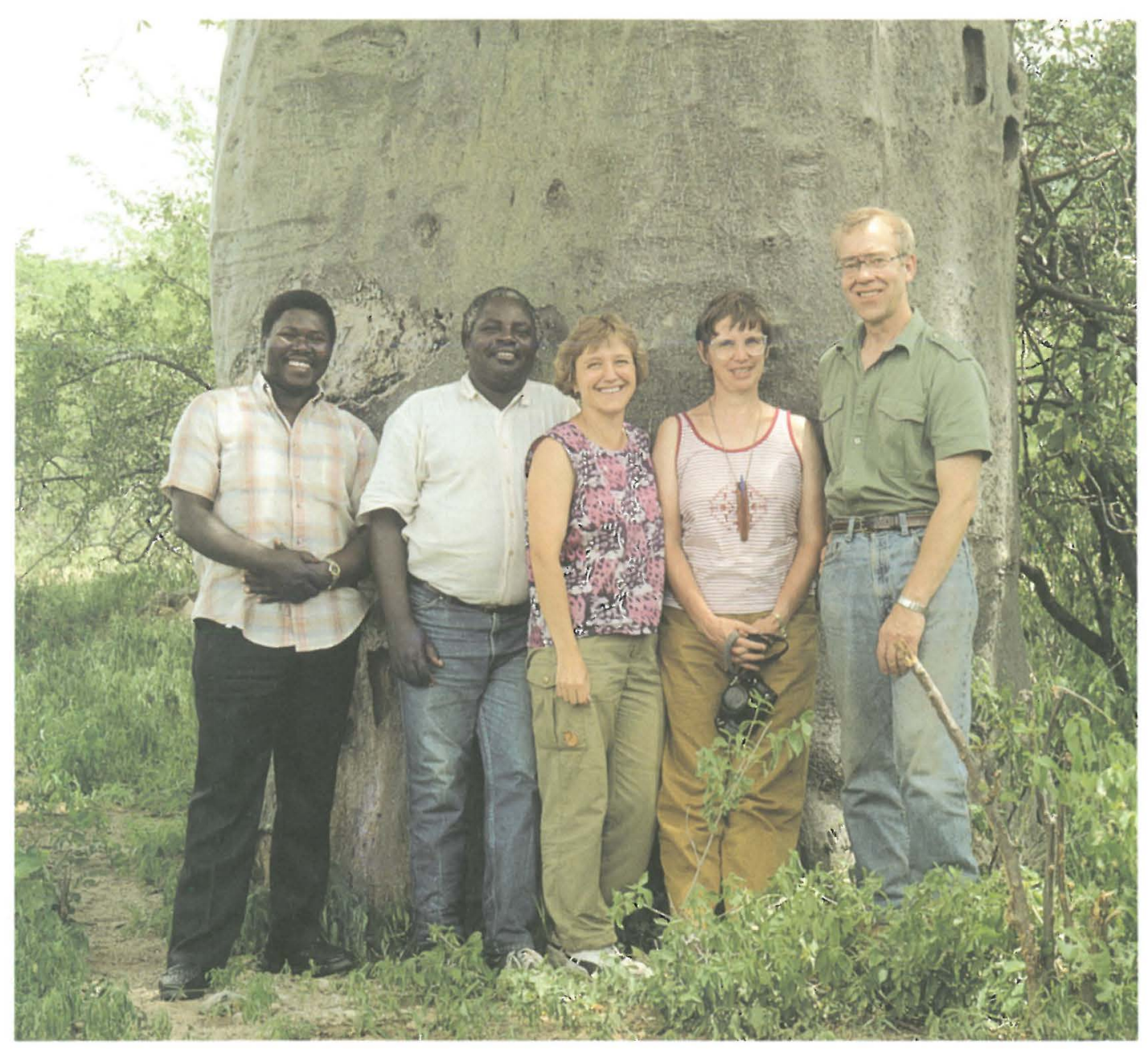

Marja Härkönen (second from right) and Tuomo Niemelä (right) with their collaborators Tiina Saarimäki (middle) and Leonard Mwasumbi (second from left) and a driver (left) in Mbuyuni, Ruaha Gorge, Tanzania. (Photo: Tiina Saarimäki, February 1993). 